\title{
Relationship between Types of Cervical SpineTrauma and Occurrence of Neurological Deficits
}

\author{
Syaiful Anwar, ${ }^{1}$ Agus Hadian Rahim, ${ }^{2}$ Farhan Anwary ${ }^{3}$ \\ ${ }^{1}$ Faculty of Medicine Universitas Padjadjaran, ${ }^{2}$ Department of Orthopaedic and Traumatology \\ Faculty of Medicine, Universitas Padjadjaran/Dr. Hasan Sadikin General Hospital Bandung, \\ ${ }^{3}$ Department of Radiology Faculty of Medicine Universitas Padjadjaran/Dr. Hasan Sadikin \\ General Hospital Bandung
}

\begin{abstract}
Background: About 3,500 people died each year due to neck injury, according to a study in the USA. Trauma at cervical spine level causes injury in soft tissue, cervical vertebrae, and spinal cord that can cause neurological deficits. The aim of this study was to analyze the relationship between type of cervical trauma and the occurrence of neurological deficits.

Methods: An analytic study was carried out to 121 medical records of patients diagnosed with cervical spine trauma at Dr. Hasan Sadikin General Hospital Bandung in the period of January 2010-December 2012. Data were classified according to age, sex, period of initial visit to hospital, mechanism of trauma, cervical trauma type, fracture's or dislocation's location (without any other vertebral injury) and neurological status. The collected data were analyzed using Chi-Square test and presented in tables.

Results: There were 121 cases of cervical spine trauma. Most patients were male and in the productive age group (30-44 years). Most of the initial visits to the hospital were in 2010 and most of the mechanism was traffic accident (46.28\%), while soft tissue injury was the most common type of cervical trauma (54.54\%) and lower cervical vertebrae was the most common location of fractures or dislocations (76.36\%). Sixty two patients were recorded with neurological deficits. Chi-Square test of relationship between the type of cervical trauma and the occurrence of neurological deficit was statistically significant $(\mathrm{p}=0.000)$.
\end{abstract}

Conclusions: There is relationship between the type of cervical trauma and occurrence of neurological deficits.

Keywords: Cervical spine trauma, neurological deficit, soft tissue injury

\section{Introduction}

Trauma at cervical spine could cause injury in its soft tissue and vertebrae. Cervical spine traumas caused various impact and severity, from the mild impact such as neck ligament injuries and in worse case vertebral injuries, to the most severe impact such as death..$^{1-4} \mathrm{~A}$ study in the United States showed that 5-10\% of those trauma was severe trauma. On the average, 3,500 people died each year due to neck injury. 2

Anatomically, spinal cord is located inside the vertebrae (vertebral foramina). Cervical vertebrae were designed to protect the spinal cord. Spinal cord is one of the central nervous system in human body. 5 . 6 If the cervical vertebrae were damaged, the spinal cord would be affected which could cause neurological deficit. Neurological deficit may vary from losing either the motor or sensory function.

The aim of this study was to analyze the association between the type of cervical trauma and occurrence of neurological deficits.

\section{Methods}

This study was a cross sectional study and conducted at Dr. Hasan Sadikin General Hospital Bandung using the medical records of patients diagnosed with cervical spine trauma from January 2010 to l December 2012. Data were taken from the patients' medical records who were admitted to the Inpatient Unit at Dr. Hasan Sadikin General Hospital. The inclusion

Correspondence: Syaiful Anwar, Faculty of Medicine, Universitas Padjadjaran, Jalan Raya Bandung-Sumedang Km.21, Jatinangor, Sumedang, Indonesia, Phone: +62 85729815515 Email: syaiful.anwar.ipung@gmail.com 
criteria were all of the patients diagnosed with trauma at cervical spine level without any other level of vertebral injury.

The collected data was grouped according to age: less than 15 years , 15-29 years , 3044 years, and more than 59 years; sex; period of initial visit to hospital as in year 2010, 2011, and 2012; mechanism of trauma e.g. in traffic accident, fall from height, blunt trauma, and others; type of cervical spine trauma e.g. in cervical vertebrae injury, cervical soft tissue injury; fracture or dislocation's location e.g. in cervical vertebrae (C1-C2), lower cervical vertebrae (C3-C7); with or without neurological deficit.

Furthermore, Chi-square test was used as statistical test where $\mathrm{p}<0.05$ was considered as significant value.

\section{Results}

This study collected about 121 medical records of patients diagnosed with cervical spine trauma from January 2010 to December 2012.

According to sex, cervical spine trauma patients were dominated by male. While, according to age distribution, most cervical spine trauma patients were aged 30-44 years. The rest of them were distributed equally in other groups. The most common cervical spine

Table 1 Distribution of Cervical Spine Trauma according to Sex, Age, Period of Initial Visit to Hospital, Mechanism of Trauma, Type of Trauma, and Location of Fracture/ Dislocation

\begin{tabular}{|c|c|}
\hline Characteristic & $\begin{array}{l}\text { Total } \\
\text { n(\%) }\end{array}$ \\
\hline \multicolumn{2}{|l|}{ Sex } \\
\hline Male & $106(87.60 \%)$ \\
\hline Female & $15(12.39 \%)$ \\
\hline \multicolumn{2}{|l|}{ Age } \\
\hline$<15$ years old & $3(2.47 \%)$ \\
\hline $15-29$ years old & $40(33.05 \%)$ \\
\hline 3044 years old & $45(28.92 \%)$ \\
\hline $45-59$ years old & $22(18.28 \%)$ \\
\hline$>59$ yearsold & $21(17.35 \%)$ \\
\hline \multicolumn{2}{|l|}{ Period of Initial Visit to Hospital } \\
\hline 2010 & $36(29.75 \%)$ \\
\hline 2011 & $33(27.27 \%)$ \\
\hline 2012 & $52(42.97 \%$ \\
\hline \multicolumn{2}{|l|}{ Mechanism of Trauma } \\
\hline Traffic Accident & $56(46.28 \%)$ \\
\hline Fall from height & $48(39.66 \%)$ \\
\hline Blunt trauma & $7(5.78 \%)$ \\
\hline Others (shot, punctured) & $10(8.26 \%)$ \\
\hline \multicolumn{2}{|l|}{ Type of trauma } \\
\hline Cervical Vertebrae Injury & $55(45.45 \%)$ \\
\hline Cervical Spine Soft Tissue Injury & $66(54.54 \%)$ \\
\hline \multicolumn{2}{|l|}{ Location of Fracture or Dislocation } \\
\hline Upper Cervical Vertebra & $13(23.63 \%)$ \\
\hline Lower Cervical Vertebra & $42(76.36 \%)$ \\
\hline
\end{tabular}


Table 2 Type of Cervical Trauma and Neurological Deficit

\begin{tabular}{lcccc}
\hline & $\begin{array}{c}\text { Neurological } \\
\text { Deficit } \\
(+\mathbf{~}\end{array}$ & $\begin{array}{c}\text { Neurological } \\
\text { Deficit } \\
(-)\end{array}$ & Total & Significance \\
\hline Cervical Vertebrae Injury & 51 & 4 & 55 & $\mathrm{p}=0.000$ \\
Cervical Spine Soft Tissue Injury & 11 & 55 & 66 & 121 \\
Total & 62 & 59 & & \\
\hline
\end{tabular}

trauma mechanism was traffic accident, which occurred in 56 people (46.28\%) (Table 1).

A number of 62 patients had neurological deficits. Fifty one of them were caused by cervical vertebral injuries while the other 11 were caused by cervical spine soft tissue injuries. Fifty nine patients did not have neurological deficits. On the other hand, there were more patients with cervical spine soft tissue injuries than patients with cervical vertebral injuries (6:5) (Table 2).

This study revealed that there was a relationship between the type of cervical spine trauma and the incidence of neurological deficit.

\section{Discussion}

This study revealed that more male patients had cervical spine trauma compared to female patients. This result corresponded with a previous study stating that cervical spine trauma occurred more in male patients. ${ }^{1,7,8}$ This higher occurrence of cervical spine trauma in males might be caused by the more dangerous activities that were performed by males such as high velocity driving.

Furthermore, cervical spine trauma cases increased from 2010 until 2012 although it seemed to decrease slightly in 2011. Most cervical spine trauma cases were found in 2012, comprising 52 cases, which was higher than in 2011 and 2010. It was probably caused by the difficulty in finding complete data from older medical records.

Moreover, most of the patients were aged 30-44 years which corresponded with a previous study stating that cervical spine trauma occurred at the age of 31 until 40 years at most. ${ }^{9}$ People at age ranging from 30 until 40 years, as mentioned above, were still in their productive age. Additionally, many activities were related to height and high velocity in productive age, like repairing pieces of roof and driving a motorcycle. Fewer cervical spine traumas could be seen in 15-year old children, since they did not performed many dangerous activities. There was also a high occurrence of cervical spine trauma ( 40 cases) at the age of 15 until 29 years .

Additionally, mechanism of cervical spine trauma was mainly traffic accident, followed by falling from height. This statement corresponded with a previous study that pointed out that most mechanism of cervical trauma are activities related to high velocity and height. ${ }^{1,10,11,14}$ Accidents in high velocity can cause sudden flexion or extension at the neck which later will cause injuries of soft tissue and the cervical vertebrae itself.

Corresponding to another previous study, in this study cervical vertebrae C3 until C7 are also found to be the main location for fractures in cervical trauma cases. ${ }^{1,10}$ It might be caused by a higher flexibility of the vertebrae at this level compared to the other vertebrae. Thus, vertebrae at this level were more prone to injuries.

In this study, the number of patients with cervical spine soft tissue injuries was more than patients with cervical vertebral injury. It corresponded with a previous study. Anatomically, soft tissues surrounded the cervical vertebrae at the outside. Thus, the cervical soft tissue was the first to be injured. But the structure of the cervical soft tissue itself was indeed soft and less tough than the cervical vertebrae. Thus, the cervical soft tissue was definitely more fragile than cervical vertebrae. 9,12 $^{2}$

Neurological deficits were more common in patients with cervical vertebral injuries than in patients with cervical spine soft tissue injuries only. Besides, cervical vertebrae injury was worse than soft tissue injury, because in vertebral injury cases, penetrated trauma occurred stronger and deeper as seen from the vertebral structure and location which were surrounded by soft tissues. Furthermore, anatomically the spinal cord was inside the vertebrae, so it was possible that this spinal cord structure was affected by the cervical vertebrae injury, which explained the occurrence of neurological deficits. 
Although neurological deficits occurred mainly in cervical vertebrae injuries, there should be consideration for the data in this study about the high occurrence of neurological deficits in soft tissue injuries (11 cases). The neurological deficits could occur when sudden flexion-extension movements caused tears at the intervertebral disc. The spinal cord would be affected so that neurological deficits might occur.

Statistical test results from the type of cervical trauma and neurological deficit variables showed significance $(p=0.000)$. $P$ was valued less than $5 \% .13$ It showed meaningful significance. Thus, it can be concluded that there is a relationship between the type of cervical trauma and incidence of neurological deficit incidence.

This study has limitation because of the difficulty to obtain complete medical records about cervical spine trauma at Dr. Hasan Sadikin General Hospital.

\section{References}

1. Torretti JA, Sengupta DK. Cervical spine trauma. Indian J Orthop. 2007; 41(4):255-67.

2. David BL, Brian SG, Edmond AH, Francisco T, Eric LL, John DH, et al. Neck trauma. Medscape. 2012. [Cited 2013 February 27]. Available from: http://emedicine. medscape.com/article/827223overview\#a0199

3. Thompson WL, Stiell IG, Clement CM, Brison RJ. Association of injury mechanism with risk cervical spine fractures. CJEM. 2009;11:14-22.
4. Milby AH, Halpern CH, Guo W, Stein SC. Prevalence of cervical spinal injury in trauma. Neurosurg Focus. 2008; 25(5):E10.

5. Moore KL, AFD. Clinically Oriented Anatomy. $5^{\text {th }}$ ed. Baltimore : Lippincot Williams and Wilkins. 2006. p. 478-545, 1046-83.

6. Rahim AH. Vertebra. Jakarta: Sagung Seto.2012.p. 46-9

7. Nathens AB. National Trauma Data Bank 2010 Annual Report. Chicago: Ammerican College Surgeon; 2010.

8. Graber MA, Kathol M. Cervical spine radiograph in trauma patient. Am Fam Physician. 2005;59(2)331-42

9. Ning GZ, Yu TQ, Feng SQ, Zhou XH, Ban DX, Liu Y, et al. Epidemiology of traumatic spinal cord injury in Tianjin, China. Spinal Cord. 2011;49(3):386-90.

10. Van den Berg ME, Castellote JM, MahilloFernandez I, de Pedro-Cuesta J. Incidence of spinal cord injury worldwide : a Systematic Review. Neuroepidemiology. 2010;34(3):184-92.

11. Lawrence SC, Robert B, Molly GK. Spinal cord injuries. 2012. [Cited 2013 February 28]. Available from: http://emedicine. medscape.com/article/793582-overview

12. Miles KA, Maimaris C, Finlay D, Barnes MR . The incidence and prognostic of radiological abnormalities in soft tissue injuries to the cervical spine. Skeletal Radiol. 2006;17(7):493-6

13. Sopiyudin DM. Statistik untuk kedokteran dan kesehatan. 5th ed. Jakarta: Salemba Medika. 2008.

14. Ryan MD, Henderson JJ. The Epidemiology of fracture and fracture-dislocation of the Cervical Spine. Injury. 2007;23(1):38-40. 